\title{
Accounting
}

\section{The effects of attitude, trust and switching cost on loyalty in commercial banks in Ho Minh City}

\section{Van Dung $\mathbf{H a}^{\mathbf{a}^{*}}$}

\begin{tabular}{l}
${ }^{a}$ Banking University Hochiminh Cit, \\
\hline C H R O N I C L E \\
\hline Article history: \\
Received September 122019 \\
Received in revised format \\
September 302019 \\
Accepted November 72019 \\
Available online \\
November 72019 \\
\hline Keywords: \\
Attitude \\
Trust \\
Switching cost \\
Loyalty \\
Bank \\
\hline
\end{tabular}

\section{Introduction}

Loyalty is considered a constant subject of discussion among researchers when it comes to attracting and keeping customers coming back to deal with banks (Tweneboah-Koduah \& Farley, 2015). Many studies have conducted experiments on trust affecting loyalty and the results confirm the positive influence of trust on customer's loyalty in all areas, including banking and finance industry (Sirdeshmukh et al., 2002; Akhgari et al., 2018). However, considering other issues like attitude, switching cost and trust affecting loyalty, very few studies have been accomplished. Switching cost is increasingly becoming a powerful barrier to help banks preserve their customers, not only that, considering the customer's attitude is an important premise in attracting and connecting customers to banking transactions (Akhgari et al., 2018; Bravo et al., 2009). Attitude is a prerequisite for increasing the trust and loyalty of customers in the banking sector (Akhgari et al., 2018). Therefore, the study of customer's loyalty needs to consider customers' attitude (Akhgari et al., 2018). Therefore, the purpose of this study is to determine and measure the influence of Attitude, Trust and Switching Cost on the Loyalty of individual customers in commercial banks in Ho Chi Minh City; on that basis, the study proposes administrative implications to improve the loyalty of individual customers at commercial banks in Ho Chi Minh City.

\footnotetext{
* Corresponding author

E-mail address: dunghv@buh.edu.vn (V.D. Ha) 


\section{Theoretical basis}

In retail banking, customer's loyalty is a strong commitment and a willingness to repeat the return to use a product/service in the future. According to Lam et al. (2004), customer's loyalty is the repeat of customers about the use of suppliers' products and services. Customer's loyalty to banking services has become the focus of marketers and researchers. It is very important because it affects the profitability of the banks (Keisidou et al., 2013). Meanwhile trust is a solid foundation in increasing customer's satisfaction and loyalty (Schoorman et al., 2007). According to Schoorman et al. (2007), trust is customers' expectations for product/service quality, so they are ready to use them. Trust is important for banks to contact customers in the future. The attitude is the behavior of customers after they are aware of the service provider's products/services and their activities to their needs (Akhgari et al., 2018). Accordingly, Akhgari et al. (2018) argue that attitudes include hedonic attitude and utilitarian attitude; in which, hedonic attitude refers to the bank always happy, beloved, enthusiastic, friendly with customers in all transactions; and utilitarian attitude refers to the customer always thinking about the bank when needed, dealing with the bank when the need arises and all the needs are fully met by the bank. In addition, switching costs are costs that customers incur as a result of changing brands, service providers or products (Okada, 2005; Akhgari et al., 2018). Although most of the most common switching costs are financial issues, but issues such as time, relationship also need to be considered as conversion costs (Akhgari et al., 2018). Switching costs can be expressed in terms of the time and effort required to change suppliers, risk of disrupting normal customer operations during the conversion period, high cancellation fees, and irreplaceable similar products or services (Akhgari et al., 2018).

\section{The connection between Hedonic attitude and Utilitarian attitude}

Chitturi et al. (2008) define the connection between hedonic attitude and utilitarian attitude being real. Voss et al. (2003) suggest that these two types of attitudes are not connected while Homer (2008) shows an interaction. The hedonic attitude will affect the utilitarian attitude, because when there is a hedonic emotion, the customer will take more specific and practical actions (Pham, 2004). Schwarz (2012) further demonstrates that the hedonic attitude will affect the mind and the customer will take specific actions more utilitarian. Based on that, the study proposed the following hypothesis:

\section{Hypothesis H1: Hedonic attitude positively affects Utilitarian attitude.}

\section{The relationship between Attitude and Trust}

Researchers have demonstrated that Attitude will change customer's trust (He et al., 2012; Palmatier et al., 2006). The premise of trust often includes attitude (Homer, 2008; Overby \& Lee, 2006), so that attitude has a direct influence on trust. Moreover, attitudes toward services will increase confidence in the brand image and trust in service organizations (Batra \& Homer, 2004; Chaudhuri \& Holbrook, 2001; Homer, 2008). Based on this, the study proposes the following hypotheses:

Hypothesis H2: Hedonic attitude positively affects Customer's Trust. Hypothesis H3: Utilitarian attitude positively affects Customer's Trust.

\section{The relationship between Attitude and Loyalty}

There has been much empirical evidence proving that both hedonic and utilitarian attitudes have significant positive effects on loyalty (Homer, 2008). Attitude is also the foundation to improve customer's loyalty (Ryu et al., 2010). Based on this, the study proposes the following hypotheses:

Hypothesis H4: Hedonic attitude positively affects Customer's loyalty.

Hypothesis H5: Utilitarian attitude positively affects Customer's loyalty.

\section{The relationship between Trust and Loyalty}

Schoorman et al. (2007) assert that trust will ensure increased customer's satisfaction and promotes customer's loyalty to a higher level. In addition, Afsar et al. (2010) believe that trust established by customers can be an approach for marketing, where brand can be delivered through customer's friends and families. According to Ofori et al. (2017), trust can be the main reason explaining why they use bank services again and again. The more a bank wins customer trust, the greater its satisfaction and loyalty will be guaranteed, and there is no consequence that customers will convert to other organizations. Hasan et al. (2014) states that the values and trusts actually create customer's loyalty. Another research by Leninkumar (2017) also shows an influence of trust on loyalty. Based on that, the study proposed the following hypothesis: 


\section{The relationship between Switching cost and Loyalty}

The viability of switching cost can directly affect loyalty as commented by researchers in the banking sector (Ladhari et al., 2011). Switching costs have partly significantly affected customer's loyalty, when conversion costs are too high, customers will consider continuing to maintain a relationship with the current service provider, and therefore, customers will be more loyal. Based on that, the study proposed the following hypothesis:

Hypothesis H7: Switching cost positively influence Customer's loyalty.

\section{Research method}

The research methods used are as follows:

- Qualitative method: It is carried out in an order based on the theoretical basis and an overview of previous related studies to propose preliminary research hypotheses and models. The author then conducted a group discussion with 10 experts to add observed variables to the factors and adjust the observed variables of the factors of Attitude, Switching Cost, Trust as well as Loyalty in the preliminary research model to suit the research context at commercial banks in Ho Chi Minh City. The research results will form the basis for building a scale and questionnaire to collect data for quantitative research.

- Quantitative method: The research sample in quantitative research was conducted by convenient sampling method with sample size of 282 customers. The data is collected by the survey via a pre-designed questionnaire and sent directly to individual customers to interview and receive immediate results. The collected data is processed by SPSS 20 and AMOS 20 software including statistics, assessment of reliability of scales with Cronbach's Alpha test, exploratory factor analysis EFA with Barlett and KMO tests, Confirmatory Factor Analysis CFA and Structural Equation Model SEM to analyze the impact of Attitude, Trust and Switching Cost on the Loyalty of individual customers at Commercial Banks in Ho Chi Minh City.

\section{Table 1}

The scales belong to factors in the research model

\begin{tabular}{|c|c|c|c|c|}
\hline No. & Factor & Code & Scale & Source \\
\hline 1 & \multirow{4}{*}{ Hedonic attitude } & TT1 & The bank I am dealing with is very happy with its customers & \multirow{4}{*}{$\begin{array}{l}\text { Akhgari et al. } \\
\text { (2018) }\end{array}$} \\
\hline 2 & & TT2 & The bank I am dealing with is very dear to its customers & \\
\hline 3 & & TT3 & The bank I am dealing with is very enthusiastic with its customers & \\
\hline 4 & & TT4 & The bank I am dealing with is very friendly with its customer & \\
\hline 5 & \multirow{4}{*}{ Utilitarian attitude } & TD1 & I always deal with the bank with the most needed products and services when needed & \multirow{4}{*}{$\begin{array}{l}\text { Akhgari et al. } \\
\text { (2018) }\end{array}$} \\
\hline 6 & & TD2 & I always think about the bank I am dealing with when needed & \\
\hline 7 & & TD3 & All my needs are satisfactorily met by the bank & \\
\hline 8 & & TD4 & I always give priority to the bank I am dealing with for all my transactions & \\
\hline 9 & \multirow{4}{*}{ Trust } & NT1 & The transactions of the bank I am dealing with are very reliable & \multirow{4}{*}{$\begin{array}{l}\text { Akhgari et al. } \\
\quad(2018)\end{array}$} \\
\hline 10 & & NT2 & The bank I am dealing with has the ability to serve its customers & \\
\hline 11 & & NT3 & The bank I am dealing with is very thoughtful to its customers & \\
\hline 12 & & NT4 & The bank I am dealing with proactively connects to its customers & \\
\hline 13 & \multirow{3}{*}{ Switching cost } & CP1 & It will take me a lot of time and effort to get acquainted with a new bank & \multirow{3}{*}{$\begin{array}{l}\text { Akhgari et al. } \\
\quad(2018)\end{array}$} \\
\hline 14 & & $\mathrm{CP} 2$ & It would cost me too much to switch to a new bank & \\
\hline 15 & & $\mathrm{CP} 3$ & I will have procedural trouble when transferring other bank transactions & \\
\hline 16 & \multirow{4}{*}{ Loyalty } & TT1 & I will continue to use the banking service I am trading in the future & \multirow{4}{*}{$\begin{array}{l}\text { Akhgari et al. } \\
\text { (2018) }\end{array}$} \\
\hline 17 & & TT2 & I would recommend my primary financial institution to those seeking my advice on such matters & \\
\hline 18 & & TT3 & I would recommend the bank to friends and my family & \\
\hline 19 & & TT4 & $\begin{array}{l}\text { I would post positive messages about my primary financial institution on internet or community } \\
\text { message boards }\end{array}$ & \\
\hline
\end{tabular}

According to Trong and Nguyen (2008), the sample size must be at least four or five times the number of observed variables. Thus, in this study, the authors use a minimum number of research votes corresponding to 19 observed variables: $5 \times 19=95$ observations. However, to ensure the persuasion and quality of the model results, the author conducted a survey of 300 votes, including 282 valid questionnaires with all the information on the questionnaire. Among 282 customers, 128 female customers accounted for $45.4 \%$ and 154 males accounted for $54.6 \%$, the result showed that the difference between male and female customers was not too much. Education is mainly university and postgraduate with the proportion accounting for $53.9 \%$. Age 
ranges mainly from 35 to 45 years old, accounting for $55.0 \%$. The income level from 5 to less than 10 million VND / month accounts for the highest proportion with $50.7 \%$.

Table 2

Descriptive statistics results

\begin{tabular}{|c|c|c|c|}
\hline Variable & Content & Frequency (n) & Percent (\%) \\
\hline \multirow{2}{*}{ Gender } & Male & 154 & 54.6 \\
\hline & Female & 128 & 45.4 \\
\hline \multirow{3}{*}{ Education } & Intermediate and college & 17 & 6.0 \\
\hline & University and Postgraduate & 152 & 53.9 \\
\hline & Other & 113 & 40.1 \\
\hline \multirow{4}{*}{ Age } & $<25$ & 11 & 3.9 \\
\hline & 25 - under 35 & 81 & 28.7 \\
\hline & 35 - under 45 & 155 & 55.0 \\
\hline & $>45$ & 35 & 12.4 \\
\hline \multirow{3}{*}{ Income } & $<5$ million VND & 31 & 11.0 \\
\hline & $5-10$ million VND & 143 & 50.7 \\
\hline & $>10$ million VND & 108 & 38.3 \\
\hline
\end{tabular}

\section{Research results}

Source: SPSS Analysis Results.

The results of the reliability test of the scale of factors show that, Cronbach's Alpha coefficient reaches the maximum value of 0.906 belongs to the utilitarian attitude factor; the lowest Cronbach's Alpha coefficient is 0.750, which belongs to the Switching Cost factor. All Cronbach's Alpha coefficients of the factors are relatively high from 0.7 upwards. The correlation coefficient of the total variables is greater than 0.3 , showing that the variables are closely correlated, ensuring all variables (19 variables of 5 factor groups) meet the requirements of Structural Equation Model SEM analysis.

Table 3

Cronbach's Alpha analysis results

\begin{tabular}{llc}
\hline Factor & Cronbach's alpha \\
\hline Hedonic attitude & 0.826 \\
Utilitarian attitude & 0.906 \\
Trust & 0.803 & 4 \\
Switching cost & 0.750 & 4 \\
Loyalty & 0.833 \\
\hline
\end{tabular}

Source: SPSS Analysis Results.

All 19 variables belonging to factors that fulfill the conditions of analysis. The reliability of Cronbach's Alpha is included in the Exploratory Factor Analysis (EFA). EFA is used to examine the structure of a scale of factors: Hedonic attitude, Utilitarian attitude, Trust, Switching cost and Loyalty. After the EFA process has been performed, the factors will be tested to clean the data. Conducting EFA analysis for a total of 19 variables of the scales belonging to factors, the study obtained the results presented in Table 4.

\section{Table 4}

EFA analysis results

\begin{tabular}{|c|c|c|}
\hline & $\mathrm{KMO}$ & 0.770 \\
\hline \multirow{3}{*}{ Bartlett's test of sphericity } & Approx. Chi-Square & $2,883.725$ \\
\hline & Df & 171 \\
\hline & Sig. & 0.000 \\
\hline
\end{tabular}

The results of factor analysis obtain coefficient $\mathrm{KMO}=0.770, \mathrm{Sig} .=0.000$. This confirms the KMO value ensuring the appropriateness of exploratory factor analysis. The Chi-Square statistic of Bartlett's test is valued 2,883.725 with significance level Sig. $=0,000$. At the same time, analysis of extracted variance indicates the level of extract variance of $69,382 \%$, which shows that $69,382 \%$ of data variability explained by five factors. The scales are accepted. The stopping point when extracting factors at the fifth factor is 1,284 which is greater than 1 (this confirms that all included variables would be classified into five factor groups). The results of factor rotation show that all factors are satisfactory (factor load factor values are greater than 0.5 ) and arranged in five separate groups of factors, these are groups of factors Hedonic attitude, Utilitarian attitude, Trust, Switching cost and Loyalty. Next, perform Confirmatory Factor Analysis CFA using AMOS software with the purpose of checking the 
influence of factors together. To conduct CFA analysis, the main groups of factors included in the analysis are: Hedonic attitude, Utilitarian attitude, Trust, Switching cost and Loyalty. The results indicate that the value of Chi-square/df $=2.273$ is less than 3 , $\mathrm{GFI}=0.889$ is greater than $0.8, \mathrm{TLI}=0.922$ is greater than $0.9, \mathrm{CFI}=0.935$ is greater than 0.9 and $\mathrm{RMSEA}=0.067$ is less than 0.1 ; Therefore, it can be said that the model is suitable for market data. At the same time, the standardized weights are greater than 0.5 . That is statistically significant, so the concepts achieve convergent value. Thus, with CFA analysis results, the main factors are included in the analysis, which are: Hedonic attitude, Utilitarian attitude, Trust, Switching cost and Loyalty.

\section{Table 5}

\section{$\underline{\text { Rotated Component Matrix }}$}

\begin{tabular}{|c|c|c|c|c|c|}
\hline & \multicolumn{5}{|c|}{ Component } \\
\hline & 1 & 2 & 3 & 4 & 5 \\
\hline TD1 & 0.992 & & & & \\
\hline TD4 & 0.986 & & & & \\
\hline TD2 & 0.746 & & & & \\
\hline TD3 & 0.688 & & & & \\
\hline LTT3 & & 0.896 & & & \\
\hline LTT2 & & 0.834 & & & \\
\hline LTT4 & & 0.800 & & & \\
\hline LTT1 & & 0.743 & & & \\
\hline NT3 & & & 0.835 & & \\
\hline NT2 & & & 0.832 & & \\
\hline NT4 & & & 0.728 & & \\
\hline NT1 & & & 0.705 & & \\
\hline TT3 & & & & 0.882 & \\
\hline TT2 & & & & 0.833 & \\
\hline TT4 & & & & 0.796 & \\
\hline TT1 & & & & 0.728 & \\
\hline $\mathrm{CP} 2$ & & & & & 0.869 \\
\hline $\mathrm{CP} 1$ & & & & & 0.846 \\
\hline $\mathrm{CP} 3$ & & & & & 0.727 \\
\hline \multicolumn{6}{|c|}{ Eigenvalue $=1,284$} \\
\hline Cumulaive $\%$ & 23.763 & 39.811 & 53.241 & 62.624 & 69.382 \\
\hline
\end{tabular}

Source: SPSS Analysis Results.

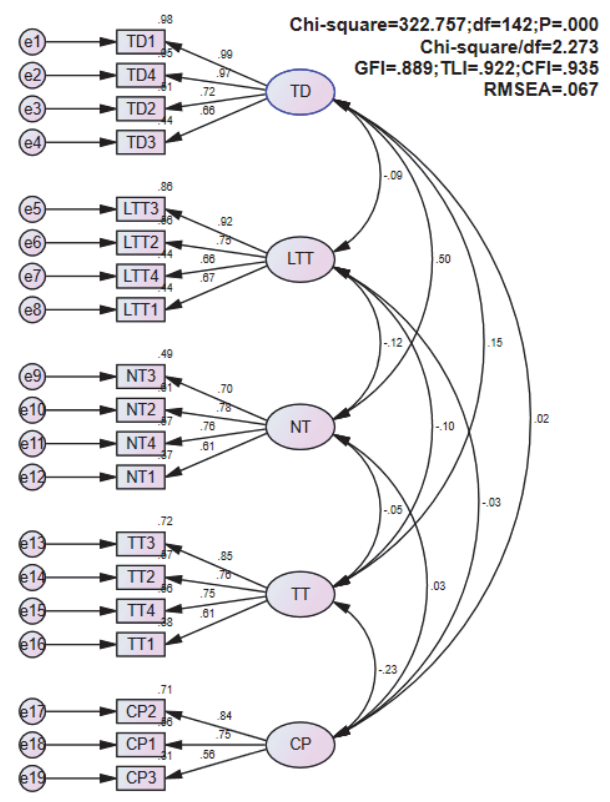

Fig. 1. CFA analysis results according to standardized coefficients TT (Hedonic attitude), TD (Utilitarian attitude), NT (Trust), CP (Switching cost), LTT (Loyalty) 
Table 6

CFA analysis results according to standardized coefficients

\begin{tabular}{ccc}
\hline No. & Content & Value \\
\hline 1 & Chi-square/df & 2.273 \\
2 & P-value của Chi-square & 0.000 \\
3 & GFI & 0.889 \\
4 & TLI & CFI \\
5 & RMSEA & 0.922 \\
6 & & 0.067 \\
\hline
\end{tabular}

Table 7

Composite reliability and Variance extracted

\begin{tabular}{|c|c|c|c|}
\hline No. & Factor & Composite reliability & Variance extracted \\
\hline 1 & Hedonic attitude & 0.899 & 0.752 \\
\hline 2 & Utilitarian attitude & 0.852 & 0.745 \\
\hline 3 & Trust & 0.863 & 0.719 \\
\hline 4 & Switching cost & 0.799 & 0.701 \\
\hline 5 & Loyalty & 0.801 & 0.703 \\
\hline
\end{tabular}

Source: Authors' calculation results.

Along with that, the research paper calculates the total reliability value and the total variance extracted to assess the reliability of the scales. The results show that the combined reliability values and total variance extracted of all factors were greater than 0.5. This shows the factors that ensure reliability when included in the analysis. And the P-value of the correlation coefficients in each pair is less than 0.05 (i.e. less than 5\%), so the correlation coefficient of each pair of concepts is different from 1 at $95 \%$ confidence. So, the concepts gain discriminatory value. To perform the analysis of the Structural Equation Model (SEM), showing the impact of attitude, trust, and switching cost on customer loyalty at Commercial banks in Ho Chi Minh City, the author transforms model obtained from CFA analysis results to Structural Equation Model.

\section{Table 8}

SEM analysis results according to standardized coefficients

\begin{tabular}{ccc}
\hline No. & Content \\
\hline 1 & Chi-square/df & Value \\
2 & P-value của Chi-square & GFI \\
3 & TLI & 0.000 \\
4 & CFI & 0.888 \\
5 & RMSEA & 0.924 \\
6 & & 0.067 \\
\hline & Source: AMOS Analysis Results
\end{tabular}

Inheriting from the CFA analysis results can be easily seen, the results of the Structural Equation Model SEM are consistent with market data. This is reflected in such indicators as: Chi-square/df value $=2.247$ less than 3 , GFI $=0.888$ greater than 0.8 , $\mathrm{TLI}=0.924$ greater than $0.9, \mathrm{CFI}=0.936$ greater than 0.9 and $\mathrm{RMSEA}=0.067$ is less than 0.1 .

\section{Table 9}

Results of the structural model analysis

\begin{tabular}{|c|c|c|c|c|c|c|}
\hline \multicolumn{3}{|c|}{ Relationship } & \multirow{2}{*}{$\begin{array}{c}\text { Estimate } \\
0.184\end{array}$} & \multirow{2}{*}{$\begin{array}{l}\text { S.E. } \\
0.080\end{array}$} & \multirow{2}{*}{$\begin{array}{l}\text { C.R. } \\
2.292\end{array}$} & \multirow{2}{*}{$\frac{\text { P-Value }}{0.022}$} \\
\hline TD & $\leftarrow$ & TT & & & & \\
\hline NT & $\leftarrow$ & TT & 0.095 & 0.049 & 1.925 & 0.004 \\
\hline NT & $\leftarrow$ & TD & 0.316 & 0.042 & 7.584 & $* * *$ \\
\hline LTT & $\leftarrow$ & $\mathrm{TT}$ & 0.115 & 0.071 & 1.618 & 0.006 \\
\hline LTT & $\leftarrow$ & TD & 0.017 & 0.061 & 0.269 & 0.008 \\
\hline LTT & $\leftarrow$ & NT & 0.144 & 0.108 & 1.331 & 0.003 \\
\hline LTT & $\leftarrow$ & $\mathrm{CP}$ & 0.055 & 0.078 & 0.714 & 0.035 \\
\hline
\end{tabular}

Source: AMOS Analysis Results.

At the same time, based on the analysis results, the P-Value of the influence relationships between the factors, we see, the PValue is less than 5\%. Therefore, the relationships among the factors Hedonic attitude, Utilitarian attitude, Trust, Switching cost and Loyalty are statistically significant in SEM. 
Table 10

Results of the structural model analysis according to standardized coefficients

\begin{tabular}{lcccc}
\hline & \multicolumn{2}{c}{ Relationship } & Standardized estimate & Standardized estimate according to the diagram \\
\hline TD & $\leftarrow$ & TT & 0.148 & 0.15 \\
NT & $\leftarrow$ & TT & 0.125 & 0.13 \\
NT & $\leftarrow$ & TD & 0.517 & 0.52 \\
LTT & $\leftarrow$ & TT & 0.117 & 0.12 \\
LTT & $\leftarrow$ & TD & 0.021 & 0.02 \\
LTT & $\leftarrow$ & NT & 0.111 & 0.11 \\
LTT & $\leftarrow$ & CP & 0.052 & 0.05 \\
\hline
\end{tabular}

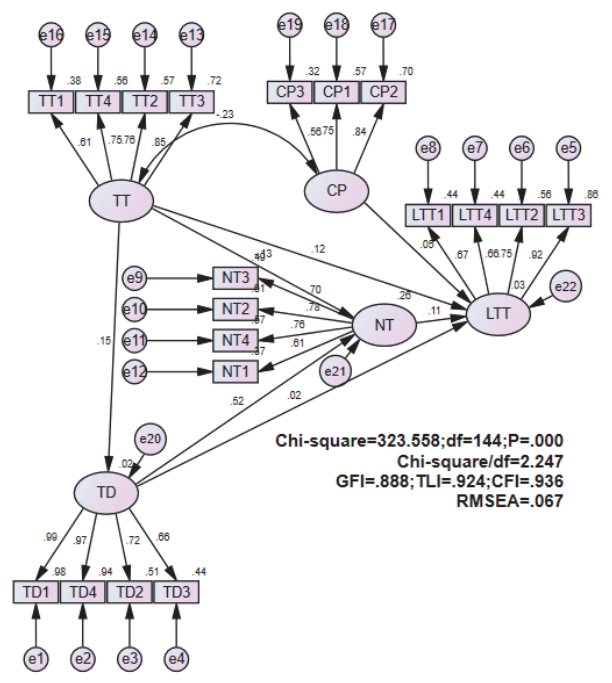

Fig. 2. Results of the structural model analysis show effects of attitude, trust, switching cost to loyalty at commercial banks in Ho Chi Minh city

TT (Hedonic attitude), TD (Utilitarian attitude), NT (Trust), CP (Switching cost), LTT (Loyalty)

Source: AMOS Analysis Results.

When considering the value of regression coefficients among factors, it shows that the regression coefficient values are all greater than zero, which means that there is a positive influence among the factors, specifically as follows:

The Hedonic attitude factor positively affects Customer's Utilitarian attitude, Trust and Loyalty with regression coefficient of $0.15 ; 0.13$ and 0.12 . This means that, when the Hedonic attitude factor is better, Customers' Utilitarian attitude, Trust and Loyalty will increase (with a one-time increase in the Hedonic attitude, Customer's Utilitarian attitude, Trust and Loyalty will increase by 0.15 times; 0.13 times and 0.12 times).

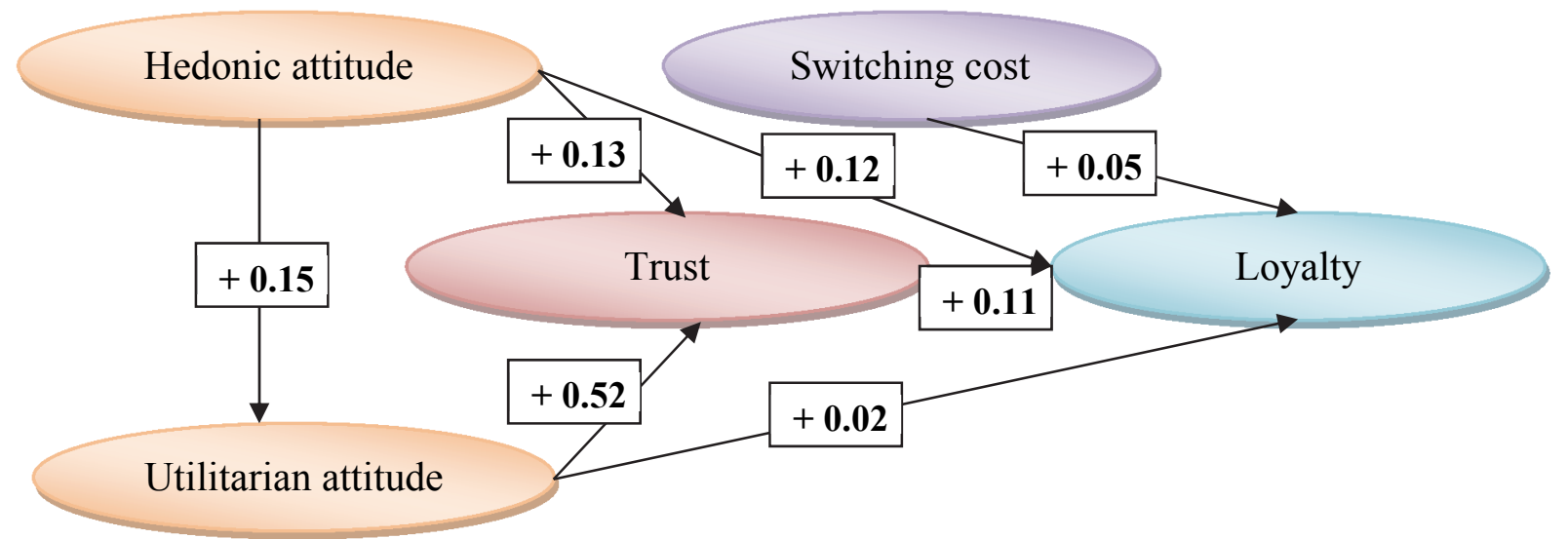

Fig. 3. Results of the structural model analysis show effects of attitude, trust, switching cost to loyalty at commercial banks in Ho Chi Minh city 
Similarly, the Utilitarian attitude factor positively affects Customers' Trust and Loyalty with regression coefficients of 0.52 and 0.02. This means that, when the Utilitarian attitude factor is better, Customers' Trust and Loyalty will increase (with a one-time increase in the Utilitarian attitude, Customers' Trust and Loyalty will increase by 0.52 times and 0.02 times). When the Trust and Switching Cost factor is better, Customer Loyalty will increase (with a one-time increase in Trust and Switching Cost, Customer Loyalty will increase by 0.11 times and 0.05 times). Thus, after analyzing the Structural Equation Model SEM, the study showed the relationship between Attitude, Trust, Switching Cost and Loyalty of individual customers, in which the Attitude factor positively affects the Trust and Loyalty; Trust and Switching Cost factors positively affect Loyalty.

\section{Conclusion and management implications}

\subsection{Conclusion}

Based on the theories related to Attitudes, Trust, Switching Cost and Loyalty, previous studies related to the topic of the research, the authors built a scale and proposed research model with 5 main factors including: (1) Hedonic attitude; (2) Utilitarian attitude; (3) Trust; (4) Switching Cost and (5) Loyalty. Next, the authors conducted qualitative research to correct and supplement errors if any, then conducted a survey and conducted a formal survey to collect the opinions of individual customers at Commercial banks in Ho Chi Minh City. With the collected database, the author conducted SPSS 20, AMOS 20 software for analysis; the study has achieved certain results as follows:

- Show the most basic concepts and scales to measure Attitude, Trust, Switching Cost and Loyalty factors; the previous research results showed the relationship as well as the influence of attitude, trust, and switching cost on Loyalty as the scientific basis for subsequent studies.

- Perform preliminary statistics on the objects of the survey such as: gender, education level, age and income.

- Assess the reliability of the scale by using Cronbach's alpha analysis technique showed that with 19 variables (including variables of the factors) all meet the evaluation requirements; Cronbach's alpha coefficients are from 0.7 or more and the correlation coefficient of the total variables is greater than 0.3 .

- The results of the exploratory factor analysis EFA show that all variables belonging to the factors meet the analytical requirements (factor load factor values are greater than 0.5); with a total of 19 variables and sorted by 5 groups of factors, which: Hedonic attitude, Utilitarian attitude, Trust, Switching cost and Loyalty.

- Confirmatory Factor Analysis shows that the model is suitable for market data, the scales ensure reliability and concepts to achieve discriminatory value.

- Structural Equation Model shows that: (1) Attitude positively affects Trust, Loyalty; (2) Trust and Switching Cost positively affect Loyalty.

\subsection{Administration implications}

Based on the results from the model, in order to increase the Loyalty of individual customers at commercial banks in Ho Chi Minh City, the study proposes some governance implications as follows:

- Enhancing the training on sales and communication skills for employees to meet customer service needs and improve customer service quality.

- Collecting and receiving customers' suggestions to promptly correct the mistakes if any when dealing with customers, in order to improve the positive attitude of customers with the bank.

- Regularly monitoring and actively contacting customers to notify customers of transactions, which showing the interest from the bank for customers and helps customers appreciate the bank trust.

- Showing to customers the specific benefits that customers have when dealing with banks and the trade-offs of costs and time that customers encounter when switching transactions to other banks through seminars, product introduction sessions for customers.

\section{Acknowledgement}

The authors would like to thank the anonymous referees for constructive comments on earlier version of this paper. 


\section{References}

Afsar, B., Rehman, Z. U., \& Shahjehan, A. (2010). Determinants of customer loyalty in the banking sector: The case of Pakistan. African Journal of Business Management, 4(6), 1040-1047.

Akhgari, M., Bruning, E. R., Finlay, J., \& Bruning, N. S. (2018). Image, performance, attitudes, trust, and loyalty in financial services. International Journal of Bank Marketing, 36(4), 744-763.

Batra, R., \& Homer, P. M. (2004). The situational impact of brand image beliefs. Journal of consumer psychology, 14(3), 318330.

Bravo, R., Montaner, T., \& Pina, J. M. (2009). The role of bank image for customers versus non-customers. International Journal of Bank Marketing, 27(4), 315-334.

Chaudhuri, A., \& Holbrook, M. B. (2001). The chain of effects from brand trust and brand affect to brand performance: the role of brand loyalty. Journal of marketing, 65(2), 81-93.

Chitturi, R., Raghunathan, R., \& Mahajan, V. (2008). Delight by design: The role of hedonic versus utilitarian benefits. Journal of marketing, 72(3), 48-63.

Hasan, H., Kiong, T. P., \& Ainuddin, R. A. (2014). Effects of perceived value and trust on customer loyalty towards foreign banks in Sabah, Malaysia. Global Journal of Emerging Trends in e-Business, Marketing and Consumer Psychology, 1(2), 137-154.

He, H., Li, Y., \& Harris, L. (2012). Social identity perspective on brand loyalty. Journal of Business Research, 65(5), 648-657.

Homer, P. M. (2008). Perceived quality and image: When all is not "rosy". Journal of Business Research, 61(7), 715-723.

Hoq, M. Z., Sultana, N., \& Amin, M. (2010). The effect of trust, customer satisfaction and image on customers' loyalty in islamic banking sector. South Asian Journal of Management, 17(1), 70.

Keisidou, E., Sarigiannidis, L., Maditinos, D. I., \& Thalassinos, E. I. (2013). Customer satisfaction, loyalty and financial performance: A holistic approach of the Greek banking sector. International Journal of Bank Marketing, 31(4), 259-288.

Ladhari, R., Souiden, N., \& Ladhari, I. (2011). Determinants of loyalty and recommendation: The role of perceived service quality, emotional satisfaction and image. Journal of Financial Services Marketing, 16(2), 111-124.

Lam, S. Y., Shankar, V., Erramilli, M. K., \& Murthy, B. (2004). Customer value, satisfaction, loyalty, and switching costs: an illustration from a business-to-business service context. Journal of the Academy of Marketing Science, 32(3), 293-311.

Leninkumar, V. (2017). The relationship between customer satisfaction and customer trust on customer loyalty. International Journal of Academic Research in Business and Social Sciences, 7(4), 450-465.

Ofori, K. S., Boateng, H., Okoe, A. F., \& Gvozdanovic, I. (2017). Examining customers' continuance intentions towards internet banking usage. Marketing Intelligence \& Planning, 35(6), 756-773.

Okada, E. M. (2005). Justification effects on consumer choice of hedonic and utilitarian goods. Journal of marketing research, 42(1), 43-53.

Overby, J. W., \& Lee, E. J. (2006). The effects of utilitarian and hedonic online shopping value on consumer preference and intentions. Journal of Business research, 59(10-11), 1160-1166.

Palmatier, R. W., Dant, R. P., Grewal, D., \& Evans, K. R. (2006). Factors influencing the effectiveness of relationship marketing: a meta-analysis. Journal of Marketing, 70(4), 136-153.

Pham, M. T. (2004). The logic of feeling. Journal of Consumer Psychology, 14(4), 360-369.

Ryu, K., Han, H., \& Jang, S. (2010). Relationships among hedonic and utilitarian values, satisfaction and behavioral intentions in the fast-casual restaurant industry. International Journal of Contemporary Hospitality Management, 22(3), 416-432.

Schoorman, F.D., Mayer, R.C. and Davis, J.H. (2007), An integrative model of organizational trust: past, present, and future, The Academy of Management Review, 32(2), 344-354.

Schwarz, N. (2012), Feelings-as-information theory, in Van Lange, P.A.M., Kruglanski, A. and Higgins, E.T. (Eds), Handbook of Theories of Social Psychology, Sage, Thousand Oaks, CA, pp. 289-308.

Sirdeshmukh, D., Singh, J. and Sabol, B. (2002), Consumer trust, value, and loyalty in relational exchanges, Journal of Marketing, 66(1), 15-37.

Tho, N.D. (2011), Methods of scientific research in business. Social Labor Publishing.

Tho, N. D., \& Trang, N.T.M. (2011), Market research syllabus. Labor Publishing.

Trong, H., \& Nguyen, M.N.C. (2008), Textbook of Data Analysis with SPSS Episodes 1 \& 2. Hong Duc Publishing, TP.HCM

Tweneboah-Koduah, E., \& Farley, Y.D. (2015). Relationship between customer satisfaction and customer loyalty in the retail banking sector of Ghana, International Journal of Business and Management, 11(1), 249-262.

Voss, K.E., Spangenberg, E.R., \& Grohmann, B. (2003). Measuring hedonic and utilitarian dimensions of consumer attitude. Journal of Marketing Research, 40(3), 310-320. 
(C) 2019 by the authors; licensee Growing Science, Canada. This is an open access article distributed under the terms and conditions of the Creative Commons Attribution (CC-BY) license (http://creativecommons.org/licenses/by/4.0/). 